\title{
"Basangero" Culture and Technology Progress: Empowering Women Concerning Family Welfare
}

\author{
Sri Rahayu* \\ Faculty of Economics and Management \\ Samawa University \\ Sumbawa, Indonesia \\ rahmaayu272@gmail.com
}

\author{
Ika Fitriyani \\ Faculty of Economics and Management \\ Samawa University \\ Sumbawa, Indonesia
}

\author{
A Asmini \\ Faculty of Economics and Management \\ Samawa University \\ Sumbawa, Indonesia
}

\begin{abstract}
The empowerment of women in various fields cannot be separated from the various obstacles that accompany women. Natural resource wealth without the participation of the government and society will not be able to bring society to prosperity. In general, the obstacles that are often faced by housewives are lowincome levels, control of production facilities in a small group of people, and the lack of skills and knowledge possessed by women in Labuhan Badas District. The method used is a quantitative method with an associative approach. The collected data were processed using a quantitative approach with a descriptive format. The analysis technique used to analyze the data is the analysis of Structural Equation Model-Partial Least Square. The results show that limited human resources, low knowledge, and skills make most of the housewives in Labuhan Badas sub-district only work according to their abilities, one of which is doing "basangero" activities, which is selling fish by going around from one village to another. This is due to their low ability to utilize technology, inability to buy mobile phones that can be used as a means of promoting their business, and the "basangero" is considered one of the fastest ways to sell their fish directly to the target audience or consumers to their home, and This "basangero" activity has become a habit from time to time until the modern era. The "basangero" culture is still being carried out by some housewives who work as itinerant fish traders.
\end{abstract}

Keywords-basangero culture, technology, empowerment, prosperity

\section{INTRODUCTION}

Efforts to increase the role of women in development have been implied in the basic philosophy of the Indonesian nation, namely Pancasila, the 1945 Constitution, and State Guidelines (GBHN). Pancasila as the philosophy of life of the Indonesian nation, Pancasila does not make a difference between men and women, which states that every citizen has the same status, rights, and obligations as well as opportunities in the family and society. However, the reality is that until now there are still many women who are neglected due to a lack of information and lack of awareness of women's rights as citizens. The understanding of most people is that they are not aware of the importance of women's equality in participation in planning and decision- making due to the extension of isolation [1] This is inseparable from the influence of the socio-cultural environment that does not support providing opportunities for women to participate in politics and national decisionmakers and the existence of institutions that still limit women to marginal power. Gender mainstreaming is a government strategy that is carried out rationally and systematically to achieve equality and gender justice in several aspects of human life, both within the household, community, and the state through policies and programs that take into account the experiences, aspirations, needs, and problems of women and men in planning, implementing, monitoring and evaluating all policies and programs in various fields of life and development.

The empowerment of women in various fields cannot be separated from the various obstacles that accompany women. The obstacle that often arises is the difficulty in synergizing various integrated empowerment programs. By focusing on one dimension, the development will ignore the richness and complexity of human life and societal experience. There is no reason to say that various actions to empower women cannot be synergized. The definition of integrated does not mean that all types of women's empowerment activities are carried out simultaneously. The development of women's roles in an integrated manner can be described as a series of empowerment activities that are carried out systematically and complement each other. Empowerment of women is not a program that can be implemented in a short period or is temporary. Women's empowerment must be carried out sustainably by continuing to develop the types of activities that are most appropriate for the community. Being a woman who has many roles is not as easy as imagined. Additional skills or knowledge are needed that can support the roles played by women. Today's desire to help husbands improve the family economy is not difficult. However, in reality, there are still many women, especially housewives, who do not have access to play more roles in social life. The existing access in the era of modernity is intended for humans who can manage business opportunities well which combines elements of modernity following the times. The use of modern technology cannot be avoided to support the business being managed. Therefore, empowering women is hampered from carrying out more roles such as working and starting a business to support family welfare. 
The occurrence of a development paradigm shift has a positive impact on women. Women have always been viewed not as a burden for development, but women can be made partners, even as development subjects. Women have various strategic positions to support development activities. Therefore, efforts to develop women's potential in society, nation, and state are a must as a form of empowerment from women's powerlessness so far [2] Participatory development is closely related to women's empowerment, where participatory development requires efforts and steps to prepare the community to strengthen community institutions so that they can realize progress, independence, and prosperity in an atmosphere of sustainable justice to increase dignity and to be able to escape from the apparatus. poverty and underdevelopment. This effort is a concrete manifestation of community empowerment. The empowerment of women is a process of empowering society. Every member of society in a community has the potential, ideas, and ability to bring himself and his community in a better direction, but that potential sometimes cannot develop due to certain factors. To revive the independence of women in development in their communities, initial encouragement or ideas are needed to revive their role and position in the framework of building a civil society. Rahardjo [3] states that social welfare does not only include the fulfillment of basic needs but also includes all aspects of the quality of human life (quality of life). Social welfare is a state, humans can solve the social problems they face, meet all their needs, and can maximize the social opportunities they have [4].

The problem of poverty is one of the many problems that exist in Indonesia and the Sumbawa Regency, in particular, both absolute poverty and relative poverty. Absolute poverty means that the inability of rural communities to meet the necessities of life properly based on a predetermined poverty line. Relative poverty is related to the inequality of ownership of assets and income in rural areas which also often worsens the condition of people who experience absolute poverty and have the potential to cause other social problems, such as jealousy and social unrest. The population of most rural areas in Indonesia is very large, the level of income, education, and health status are low, plus accessibility to productive factors, business capital, investment, and in obtaining information is very weak so that the progress and welfare of rural communities are far behind compared to the community. urban. The number of poor people in the Sumbawa Regency in 2017 reached 68.69 thousand people. This figure decreased by 2.97 thousand people or 0.8 percent from the previous year 2016 which amounted to 71.66 thousand people, but the decline is still far from the target of decreasing the regional government by 2 percent. The poverty rate for Sumbawa Regency is still above the poverty level for the Province of NTB. Mapping of poverty reduction program plans is necessary to increase the effectiveness of each implemented program. The expected output is that in addition to the availability of important information that can be used for system improvement from programs that have been implemented, specific recommendations based on regional resources also emerge. Women and men both do productive work, in addition to reproductive or domestic work. Women have been heavily involved in productive work or earning a living. Women in the village have to work more than men.

Various poverty reduction programs, especially in the district of Sumbawa, have been implemented by the government, including in the socio-economic, health, and education sectors. However, in its development, these programs have not been able to make a significant contribution to reducing poverty levels. The existence of gaps and persistently high poverty results in a low human development index. This is reflected in the human development index (HDI) of Sumbawa Regency which tends to run slowly over the period 2010-1017, which is shown in Table I.

TABLE I. HUMAN DEVELOPMENT INDEX (HDI) FOR SUMBAWA REGENCY

\begin{tabular}{|l|r|r|r|r|r|r|r|r|}
\hline \multirow{2}{*}{ Regency / City } & \multicolumn{7}{|c|}{ Human Development Index (HDI) } \\
\cline { 2 - 9 } Sumbawa & $\mathbf{2 0 1 0}$ & $\mathbf{2 0 1 1}$ & $\mathbf{2 0 1 2}$ & $\mathbf{2 0 1 3}$ & $\mathbf{2 0 1 4}$ & $\mathbf{2 0 1 5}$ & $\mathbf{2 0 1 6}$ & $\mathbf{2 0 1 7}$ \\
\hline Life Expectancy (years) & 64,63 & 64,96 & 65,25 & 65,58 & 65,72 & 66,02 & 66,3 & 66,58 \\
\hline Average Years of Schooling (years) & 6,84 & 7,1 & 7,14 & 7,19 & 7,31 & 7,52 & 7,53 & 7,54 \\
\hline Expected Years of Schooling (years) & 11,62 & 11,67 & 11,76 & 11,86 & 11,94 & 12,27 & 12,68 & 12,85 \\
\hline Adjusted Expenditure (thousand rupiah) & 7.138 & 7.177 & 7.299 & 7.422 & 7.519 & 7.743 & 8.070 & 8.584 \\
\hline HDI & 60,93 & 61,5 & 61,96 & 62,44 & 62,88 & 63,91 & 64,89 & 65,85 \\
\hline
\end{tabular}

Source: Central Bureau of Statistics of Sumbawa Regency (2018)

HDI can be classified into four groups, namely, high $($ HDI $=80-100)$, upper-middle $($ IPM $=66-80)$, lower-middle $($ IPM $=50-65)$ and low (HDI <50). Based on Table I, the HDI of Sumbawa Regency shows that from 2010 to 2017 there was no one in the high category in the field of human development. This is because the human development index of Sumbawa Regency is in the range of $60-65$, belonging to the lower middle level.

Labuhan Badas sub-district is used as the location of this research. Labuhan Badas sub-district is a small part of the coastal area in Sumbawa City, Sumbawa City. Nearly 40 percent of its area consists of coastal areas, which are pockets of poverty. Most housewives are seen to be active in the work of drying, boiling, and salting fish, looking for shells, knitting nets, and selling the fish using the "Basangero" method. Housewives must be clever in managing daily expenses so that some of the household needs can be accommodated. The "Basangero" culture is an activity carried out by some housewives in Labuhan Badas District, namely the activity of selling their fish by going around from village to village on foot while shouting to call people to buy the fish they sell. In the modern era and today's sophisticated technology, it turns out that there are still some people who continue to carry out activities in the traditional way and have become a culture. 
Basangero is also a culture that is usually practiced by housewives by peddling or selling fish from one village to another, one village to another, and one market to another, perishable fish causes housewives to sell their fish with 'basangero' and When the fish is not sold out, several habits are practiced by housewives in Sumbawa Regency, first, selling the fish at a low price, secondly, exchanging the fish for rice and thirdly, bringing the unsold fish home to be consumed by themselves or processed into salted fish and can be resold. The "basangero" habit is also a habit that has been practiced by housewives for a long time. The desire to get more income has now become a continuing tradition, although times have changed with sophisticated technology, the "basangero" tradition will not last. Seeing these conditions, it is ironic indeed, with the fact that technology is increasingly sophisticated, it is sufficient reason to begin to change the perspective of the government, society, and business people in the Sumbawa area, that the welfare of society, political stability and governance is supported by strong economic forces. strong will be achieved if able to empower all the potential that is owned. Low levels of income and education and a lack of skills have limited access and roles of housewives to obtain information as well as low levels of mobility. In meeting the daily needs of housewives, they always face various obstacles, but they always try to survive in their life even in difficult conditions. This situation is driven by a desire from within him to continue trying to make ends meet. This inner drive is in the form of desires, hopes, motivations, and values which are called work ethics. The importance of the role of the government, in this case, is to empower women through the active role of housewives in improving family welfare. In line with Kusnadi [5] where housewives who are directly involved in earning a living are active agents of social-economic change in society.

\section{MethodS}

The method used is a quantitative method with an associative approach. The collected data were processed using a quantitative approach with a descriptive format. The quantitative method aims to test general theories to produce specific findings, the data collection process uses research instruments, quantitative data analysis, while the descriptive format aims to explain situations that arise in the society that is the object of research [6]. Data collection was carried out through observation, questionnaires, and document recording. The analysis technique used to analyze the data is the Structural Equation Model-Partial Least Square (SEMPLS) analysis. The results of the analysis are then interpreted and concluded. The details can be seen in Fig. 1.

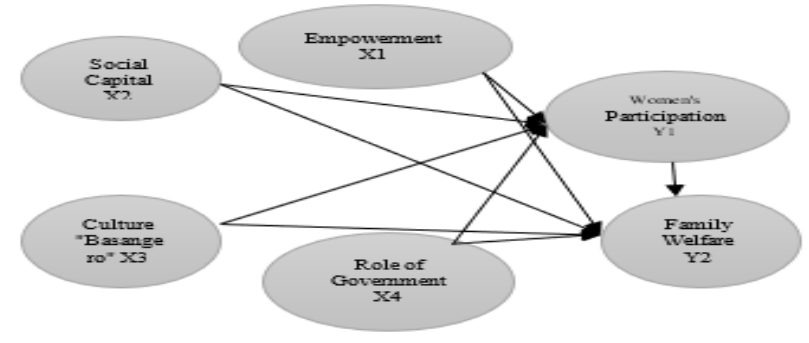

Fig. 1. Research Path Diagram

\section{RESULT AND DISCUSSION}

\section{A. Instrument Validity}

The validity test according to Sugiyono [6] shows the degree of accuracy between the data that occurs on the object and the data collected by the researcher. To find the validity of the distribution of items, we correlate the item scores with the total of these items. If the coefficient between items and total items is equal to or above 0.3 then the item is declared valid, but if the correlation value is below 0.3 then the item is declared invalid. Based on the results of the analysis of the respondent's answer score data as presented in Table II.

TABLE II. INSTRUMENT VALIDITY

\begin{tabular}{|c|c|c|c|c|}
\hline No & Indicator Code & Correlation & Significance & Information \\
\hline 1 & $\mathrm{X} 1.1$ & 0,934 & 0,000 & Valid \\
\hline 2 & $\mathrm{X} 1.2$ & 0,922 & 0,000 & Valid \\
\hline 3 & $\mathrm{X} 1.3$ & 0,554 & 0,000 & Valid \\
\hline 4 & $\mathrm{X} 2.1$ & 0,579 & 0,000 & Valid \\
\hline 5 & $\mathrm{X} 2.2$ & 0,817 & 0,000 & Valid \\
\hline 6 & $\mathrm{X} 2.3$ & 0,835 & 0,000 & Valid \\
\hline 7 & $\mathrm{X} 3.1$ & 0,954 & 0,000 & Valid \\
\hline 8 & $\mathrm{X} 3.2$ & 0,945 & 0,000 & Valid \\
\hline 9 & $\mathrm{X} 4.1$ & 0,978 & 0,000 & Valid \\
\hline 10 & $\mathrm{X} 4.2$ & 0,978 & 0,000 & Valid \\
\hline 11 & $\mathrm{X} 4.3$ & 0,969 & 0,000 & Valid \\
\hline 12 & $\mathrm{Y} 1.1$ & 0,961 & 0,000 & Valid \\
\hline 13 & $\mathrm{Y} 1.2$ & 0,984 & 0,000 & Valid \\
\hline 14 & $\mathrm{Y} 1.3$ & 0,969 & 0,000 & Valid \\
\hline 15 & $\mathrm{Y} 2.1$ & 0,956 & 0,000 & Valid \\
\hline 16 & $\mathrm{Y} 2.2$ & 0,956 & 0,000 & Valid \\
\hline 17 & $\mathrm{Y} 2.3$ & 0,925 & 0,000 & Valid \\
\hline
\end{tabular}

Based on Table II, the correlation value for all indicators $>0.30$, the smallest value is 0.579 , is the X2.1 (4) indicator and the biggest is for the Y1.2 (13) indicator of 0.984. All of them have a significance of less than 0.05 .

\section{B. Instrument Reliability}

Reliability testing in this study used Cronbach's alpha coefficient. Nunallly [7] states that a research instrument has identified sufficient reliability if the Cronbach's Alpha coefficient is greater than or equal to 0.50 . For reliability testing, reliability processing was carried out using SPSS whose processing results were listed in Table III.

TABLE III. INSTRUMENT RELIABILITY TEST

\begin{tabular}{|c|l|c|c|}
\hline No & \multicolumn{1}{|c|}{ Variable } & $\begin{array}{c}\text { Cronbach's } \\
\text { alpha }\end{array}$ & Information \\
\hline 1. & Empowerment (X1) & 0,748 & Reliable \\
\hline 2. & Social Capital (X2) & 0,603 & Reliable \\
\hline 3. & "Basangero" Culture (X3) & 0,889 & Reliable \\
\hline 4. & Role of Government (X4) & 0,973 & Reliable \\
\hline 5. & Women's Participation (Y1) & 0,969 & Reliable \\
\hline 6. & Family Welfare (Y2) & 0,910 & Reliable \\
\hline
\end{tabular}

In Table III, it can be seen that all of Cronbach's Alpha coefficients have values above 0.60 , namely with the smallest range of 0.603 to the largest of 0.973 . This means that all questionnaires as a research instrument are reliable to measure the variables. Based on the results of validity and reliability testing, it can be stated that all items of the research instrument are adequate to be used as a means of collecting data. 


\section{Evaluate the Inner Model}

Inner model evaluation includes two main things, namely evaluation of model fit (goodness of fit) and evaluation of the effect of exogenous variables on endogenous variables through hypothesis testing. Evaluation of model fit (goodness of fit) and evaluation of the effect of exogenous variables on endogenous variables refer to the output of the Structural Equation Model-Partial Least Square. Structural models resulting from Partial Least Square processing need to be evaluated using R-square for each dependent variable, and R-square adjusted predictive prevalence to see the effect of exogenous latent constructs on endogenous variables. To evaluate the Goodness of Fit the structural model is shown in Table IV which contains the R-square coefficient for each endogenous variable.

TABLE IV. R-SQUARE VALUE

\begin{tabular}{|l|c|c|c|}
\hline Endogenous Variables & $\boldsymbol{R}$-Square & $\boldsymbol{R}$-Square Adjusted & Information \\
\hline Women's Participation & 0,868 & 0,861 & Strong \\
\hline Family Welfare & 0,580 & 0,562 & Moderate \\
\hline
\end{tabular}

Based on Table IV shows the R-Square value for each endogenous variable. According to Ghozali [8], the RSquare value between $0.67-1.00$ indicates that the model is good, while the R-Square range between 0.34-0.66 indicates a moderate structural model, and if the R-Square is smaller than 0.33 indicates that the model is weak. Based on the $\mathrm{R}^{2}$ in Table III, the $\mathrm{Q}^{2}$ or Stone Geiser Q-Square test can be calculated, namely:

$$
\begin{aligned}
Q^{2} & =1-\left\{\left(1-R_{1}^{2}\right)\left(1-R_{2}^{2}\right)\right\} \\
\mathrm{Q}^{2} & =1-\{1-0,868)(1-0,580)\} \\
\mathrm{Q}^{2} & =1-0,0554 \\
\mathrm{Q}^{2} & =0,946
\end{aligned}
$$

The $\mathrm{Q}^{2}$ value of 0.946 means that 94.6 percent of the variation in family welfare in Labuhan Badas District can be explained by variations in empowerment, social capital, "basangero" culture, the role of government, and women's participation, while the remaining 5.4 percent is explained by variables others outside the research variables.

\section{Direct and Indirect Effect Testing}

To analyze the direct effect of a construct on other constructs according to the research hypothesis, it can be seen by evaluating the Path Coefficients accompanied by tStatistic and $\mathrm{p}$-Value which can be presented in Table V.

TABLE V. DIRECT INFLUENCE BETWEEN EMPOWERMENT CONSTRUCTS, SOCIAL CAPITAL, "BASANGERO" CULTURE, GOVERNMENT ROLE, WOMEN'S PARTICIPATION AND FAMILY

\section{WELFARE}

\begin{tabular}{|l|l|l|l|l|l|}
\hline Construct & $\begin{array}{c}\text { Original } \\
\text { Sample }\end{array}$ & $\begin{array}{c}\text { Standard } \\
\text { Deviation }\end{array}$ & $\begin{array}{c}\boldsymbol{T} \text { - } \\
\text { Statistic }\end{array}$ & $\begin{array}{c}\boldsymbol{P} \\
\text { Values }\end{array}$ & Significance \\
\hline $\mathrm{X} 1 \rightarrow \mathrm{Y} 1$ & 0,231 & 0,106 & 2,177 & 0,030 & Signifikan \\
\hline $\mathrm{X} 2 \rightarrow \mathrm{Y} 1$ & 0,351 & 0,092 & 3,828 & 0,000 & Signifikan \\
\hline $\mathrm{X} 3 \rightarrow \mathrm{Y} 1$ & 0,095 & 0,091 & 1,039 & 0,299 & $\begin{array}{l}\text { non } \\
\text { signifikan }\end{array}$ \\
\hline $\mathrm{X} 4 \rightarrow \mathrm{Y} 1$ & 0,325 & 0,119 & 2,741 & 0,006 & Signifikan \\
\hline $\mathrm{X} 1 \rightarrow \mathrm{Y} 2$ & 0,119 & 0,057 & 2,100 & 0,036 & Signifikan \\
\hline $\mathrm{X} 2 \rightarrow \mathrm{Y} 2$ & 0,209 & 0,056 & 3,724 & 0,000 & Signifikan \\
\hline $\mathrm{X} 3 \rightarrow \mathrm{Y} 2$ & 0,283 & 0,050 & 5,636 & 0,000 & Signifikan \\
\hline $\mathrm{X} 4 \rightarrow \mathrm{Y} 2$ & 0,296 & 0,061 & 4,880 & 0,000 & Signifikan \\
\hline $\mathrm{Y} 1 \rightarrow \mathrm{Y} 2$ & 0,289 & 0,062 & 4,631 & 0,000 & Signifikan \\
\hline
\end{tabular}

Information: $\mathrm{X} 1$ = empowerment; $\mathrm{X} 2=$ social capital; $\mathrm{X} 3=$ "basangero" culture; $\mathrm{X} 4=$ the role of government; $\mathrm{Y} 1=$ female participation; $\mathrm{Y} 2=$ family welfare

\section{Source: Processed Data}

Based on Table V, it can be seen that all exogenous variables or constructs have a direct effect on endogenous variables with $\mathrm{P}$ values less than 0.05 or with a $\mathrm{t}$-count greater than \pm 1.96 , and with a positive relationship.

TABLE VI. FACTOR LOADING CONSTRUCTS OF EMPOWERMENT, SOCIAL CAPITAL, "BASANGERO" CULTURE, ROLE OF GOVERNMENT, WOMEN'S PARTICIPATION AND FAMILY WELFARE

\begin{tabular}{|c|c|c|c|c|}
\hline $\begin{array}{c}\text { Relationship } \\
\text { Construction } \\
\text { indicators }\end{array}$ & $\begin{array}{c}\text { Original } \\
\text { sampel }\end{array}$ & $\begin{array}{c}\text { Standard } \\
\text { Deviation }\end{array}$ & T Statistics & $\boldsymbol{P}$ Values \\
\hline $\mathrm{X} 1.1 \leftarrow \mathrm{X} 1$ & 0,826 & 0,060 & 13,709 & 0,000 \\
\hline $\mathrm{X} 1.2 \leftarrow \mathrm{X} 1$ & 0,791 & 0,061 & 13,007 & 0,000 \\
\hline $\mathrm{X} 1.3 \leftarrow \mathrm{X} 1$ & 0,684 & 0,109 & 6,304 & 0,000 \\
\hline $\mathrm{X} 2.1 \leftarrow \mathrm{X} 2$ & 0,759 & 0,065 & 11,705 & 0,000 \\
\hline $\mathrm{X} 2.2 \leftarrow \mathrm{X} 2$ & 0,804 & 0,037 & 21,668 & 0,000 \\
\hline $\mathrm{X} 2.3 \leftarrow \mathrm{X} 2$ & 0,822 & 0,047 & 17,557 & 0,000 \\
\hline $\mathrm{X} 3.1 \leftarrow \mathrm{X} 3$ & 0,887 & 0,028 & 32,015 & 0,000 \\
\hline $\mathrm{X} 3.2 \leftarrow \mathrm{X} 3$ & 0,904 & 0,025 & 36,632 & 0,000 \\
\hline $\mathrm{X} 4.1 \leftarrow \mathrm{X} 4$ & 0,970 & 0,011 & 85,222 & 0,000 \\
\hline $\mathrm{X} 4.2 \leftarrow \mathrm{X} 4$ & 0,964 & 0,014 & 67,714 & 0,000 \\
\hline $\mathrm{X} 4.3 \leftarrow \mathrm{X} 4$ & 0,952 & 0,020 & 48,043 & 0,000 \\
\hline $\mathrm{Y} 1.1 \leftarrow \mathrm{Y} 1$ & 0,950 & 0,017 & 55,691 & 0,000 \\
\hline $\mathrm{Y} 1.2 \leftarrow \mathrm{Y} 1$ & 0,963 & 0,013 & 73,984 & 0,000 \\
\hline $\mathrm{Y} 1.3 \leftarrow \mathrm{Y} 1$ & 0,948 & 0,023 & 41,646 & 0,000 \\
\hline $\mathrm{Y} 2.1 \leftarrow \mathrm{Y} 2$ & 0,926 & 0,016 & 57,377 & 0,000 \\
\hline $\mathrm{Y} 2.2 \leftarrow \mathrm{Y} 2$ & 0,930 & 0,022 & 42,273 & 0,000 \\
\hline $\mathrm{Y} 2.3 \leftarrow \mathrm{Y} 2$ & 0,926 & 0,019 & 48,204 & 0,000 \\
\hline
\end{tabular}

Source: Processed Data

It can be seen that all indicators for all constructs have a loading factor (original sample) of more than 0.6 , with a probability of less than 0.05 . Thus it can be stated that all indicators in the variables: (1) empowerment, (2) social capital; (3) "basangero" culture; (4) the role of government; (5) Women's participation and (6) family welfare are proven to be valid informing their respective constructs. Based on the research results, it is proven that women's participation can help their family's needs, the "basangero" culture is carried out by some housewives in Labuhan Badas District because they do not have other abilities other than trading activities, even though they have to go around from village to village on foot, but for the sake of their families continue to carry out "basangero" activities. The government has made efforts by providing training to housewives, one of which is providing sewing training and training in making various foods in the hope that with these skills, housewives can be empowered. However, it turns out that based on the research results that the "basangero" culture practiced by some housewives does not have a positive and significant effect, this is because the "basangero" culture, which is selling fish by traveling from village to village, is practiced by some housewives only during the season. fish, this affects the activities of housewives. However, in this study, there is strength in social capital, the higher norms, trust, and networks between the community and the government in Labuhan Badas District are a reflection of the increasing social capital in influencing the active role of women. High norms are rules that must be obeyed and followed by all levels of society in a particular social entity and these rules 
are not written but are understood as determining good behavior patterns in the context of social relations and when these norms are violated there are social sanctions given for those who violate [9].

Norms can encourage high mutual trust and higher mutual trust in influencing women's activities can encourage networks between communities and the government in improving welfare. Social capital plays a very important role in increasing motivation and innovation so that it can encourage economic activity to grow well and natural resources can be made effective as physical capital for economic development because, without good economic growth, social capital will not run effectively and efficiently [10]. Mutually beneficial social capital facilities are collective actions that can shape the quality and quantity of social interactions in social life [11]. According to Yustika [12] states that the policies issued by the government are principally aimed at improving the level of people's welfare. Todaro [13] explains that the importance of the role of government is manifested in a policy for the realization of economic, social, and institutional transformations that have a positive impact on the living conditions of the people.

The indirect effect is the result of the influence through mediation by several exogenous and endogenous variables. The value of the direct effect (loading factor) is standardized from the variables it passes [14]. Based on the results of processed data with Partial Least Square, the indirect effect of a variable or research construct is presented in Table VII.

TABLE VII. INDIRECT EFFECT OF AN EXOGENOUS VARIABLE ON ENDOGENOUS VARIABLES THROUGH MEDIATION VARIABLES

\begin{tabular}{|c|c|c|c|c|c|c|}
\hline $\begin{array}{c}\text { Relations } \\
\text { Between } \\
\text { Variables }\end{array}$ & $\begin{array}{c}\text { Mediation } \\
\text { Variables }\end{array}$ & $\begin{array}{c}\text { Original } \\
\text { Sample }\end{array}$ & $\begin{array}{c}\text { Standard } \\
\text { Deviation }\end{array}$ & $\begin{array}{c}\mathbf{t}- \\
\text { Statistics }\end{array}$ & $\begin{array}{c}\text { P- } \\
\text { Value }\end{array}$ & Significance \\
\hline $\mathrm{X} 1 \rightarrow \mathrm{Y} 2$ & $\mathrm{Y} 1$ & 0,067 & 0,030 & 2,236 & 0,026 & Significant \\
\hline $\mathrm{X} 2 \rightarrow \mathrm{Y} 2$ & $\mathrm{Y} 1$ & 0,101 & 0,036 & 2,847 & 0,005 & Significant \\
\hline $\mathrm{X} 3 \rightarrow \mathrm{Y} 2$ & $\mathrm{Y} 1$ & 0,027 & 0,027 & 1,030 & 0,304 & $\begin{array}{c}\text { Non- } \\
\text { Significant }\end{array}$ \\
\hline $\mathrm{X} 4 \rightarrow \mathrm{Y} 2$ & $\mathrm{Y} 1$ & 0,094 & 0,044 & 2,153 & 0,032 & Significant \\
\hline
\end{tabular}

Based on Table VII, which contains the coefficient of indirect effects, which can be divided into four parts, the effect of an indirect relationship through the mediating variable of women's participation. The indirect effects are as follows: (1) The indirect effect of empowerment on family welfare through women's participation; (2) The indirect effect of social capital on family welfare through women's participation; (3) Indirect influence of the basangero culture on family welfare through women's participation; (4) The indirect effect of the role of government on family welfare through women's participation.

If the independent variable no longer has an influence on the dependent variable after controlling the mediator variable, it is declared perfect or complete mediation and if the effect of the independent variable on the dependent variable decreases after controlling the mediator variable, it is stated that partial mediation has occurred [15]. The mediational hypothesis is generally tested in two ways or strategies, namely: the causal step, based on the provisions of Kenny [15], and the product of coefficient multiplication strategy, which is based on testing the significance of the indirect effect or indirect effects.

An understanding of the concept of empowerment cannot be separated from an understanding of empowering humans, because empowerment is a continuous effort to make people more creative and have skills for the advancement of society itself in their social life. Widayanti [16] argues that community empowerment is a public concern that is considered as one of the approaches in overcoming social problems and poverty, the most important thing that has been the concern of various elements ranging from the government, business world, and society. Community empowerment is an effort to provide power or strength to the community so that people can get out of the social problems and poverty problems they are facing. Community empowerment is also intended to make society independent so that people can face various challenges in life. Low levels of income and education and a lack of skills contribute to the low standard of living of the community. In this condition, the level of health and environmental cleanliness is no longer considered. So that their settlements do not meet health standards and are not equipped with adequate sanitation. The consumption pattern is not balanced, the nutrients needed by the body are not fulfilled. So that the health level of family members is also very low [5].

Mubarak [17] states that empowerment programs cannot be carried out only in one cycle and stop at one particular stage, but empowerment must be carried out continuously and must be continuously improved. For this reason, it is necessary to have empowerment by the government and related parties to increase the knowledge and skills of housewives so that they can create various products of high economic value with an entrepreneurial orientation so that women gain prosperity more proactively. It is necessary to understand in simple terms about economic growth in the family due to the absence of gender inequality and without the influence of cultural construction that establishes women in the working area of wells, mattresses, and kitchens, of course, it will foster an increased economic level, because it is not just a father who becomes the backbone of earning a living, but a mother can also help find income to increase family income by working outside the home, not just squabbling inside the house [18]. With the additional economy of a mother, who can generate her income, family matters will be lighter without relying on the income from the father alone, so all the necessary needs can be obtained, such as buy nutritious food, buy environmentally friendly household furniture, hire a maid to clean the house to make it more comfortable, and can meet the educational needs of children with what they need. That way the family can improve for better quality.

Empowerment, as a follow-up form of sustainable development, leads to the formation of the gender capacity of women and society in general in improving their standard of living through the ability to solve problems with their strength. This context is what distinguishes the understanding of empowerment from sustainable development and development. Mayer and Louise [19] state 
that the approach to empowering women and society is generally in line with the "bottom-up" paradigm which is characterized by three characteristics, namely. (1) Enable women and society to identify important issues. (2) Provide a source of strength to women and society in general in making decisions on all aspects of development programs, including at the design, strategy, and management stages. (3) Measuring success is not in terms of improvements that can be measured in terms of intervention results, but qualitatively measures control over decisions that affect the lives and health of women themselves and society in general.

The current phenomenon is the use of Information Technology to assist women in several fields such as trade and entrepreneurship as a source of information and as a means to promote and market their products, one of which is through online trading. Empowerment of women in the economic sector, namely the use of information technology for business, has become a phenomenon today with the rise of internet-based online businesses. The use of the internet for online businesses is widely used by women because they are more flexible in running their business from home so that their duties and responsibilities towards the family are still fulfilled [20]. However, due to limited human resources, low knowledge, and skills, most of the housewives in Labuhan Badas sub-district only work according to their abilities, one of which is doing "basangero" activities, which is selling fish by going around from one village to another. This is due to their low ability to utilize technology, inability to buy mobile phones that can be used as a means of promoting their business, and the "basangero" is considered one of the fastest ways to sell their fish directly to the target audience or consumers to their home, and This "basangero" activity has become a habit from time to time until the modern era. The "basangero" culture is still being carried out by some housewives who work as itinerant fish traders.

\section{CONCLUSION}

Empowerment, social capital, and the role of government have a positive and significant effect on women's participation in Labuhan Badas District, while the "basangero" culture does not have a significant effect on women's participation. Although the results in this study indicate that the "basangero" culture does not have a significant effect on women's participation, the "basangero" culture remains an activity that is carried out by some housewives to be able to increase family income, apart from being a tradition, also to survive. Most of the housewives in Labuhan Badas District do not have the expertise and skills, but with the strength of social capital, social relationships between people can make their lives harmonious, peaceful, and prosperous. The habit of selling fish from one village to another on foot is called "basangero", although times have changed, the "basangero" habit has become a tradition that is still being practiced. By integrating the considerations of gender justice and equality strategies into government policies and the use of technological advances that can be balanced with the empowerment of women and the role of families that can overcome the different roles of women and men to choose the appropriate interests and talents without being limited by patriarchal dogmas can certainly add to a wider space for movement with the community or quality women, so women's welfare and empowerment can be achieved. One form of government support for the acceleration of economic development is by making policies that are conducive to the investment climate, development of the business world, and increasing the entrepreneurial capacity of business actors. To make these policies, accurate and complete data is needed. The wealth of Sumbawa's natural resources without the participation of the government and society will not be able to bring society to prosperity. In general, the obstacles that are often faced by housewives are low-income levels, control of production facilities in a small group of people, and the lack of skills and knowledge possessed by women in Labuhan Badas District. Limited human resources, low knowledge, and skills make the housewives in Labuhan Badas sub-district mostly only work according to their abilities, one of which is doing "basangero" activities, which is selling fish by going around from one village to another. This is due to their low ability to utilize technology, inability to buy mobile phones that can be used as a means of promoting their business, and the "basangero" is considered one of the fastest ways to sell their fish directly to the target audience or consumers to their home, and This "basangero" activity has become a habit from time to time until the modern era. The "basangero" culture is still being carried out by some housewives who work as itinerant fish traders.

\section{REFERENCES}

[1] Hubeis, Aida Vitalaya S. Pemberdayaan perempuan dari masa ke masa. PT Penerbit IPB Press, 2011.

[2] Remiswal, Dr, S. AG, and M. Pd. "Menggugah Partisipasi Gender di Lingkungan Komunitas Lokal." Yogyakarta: Graha Ilmu (2013).

[3] Rahardjo, Satjipto. Penegakan hukum progresif. Penerbit Buku Kompas, 2010.

[4] Midgley, James. "Globalization, capitalism and social welfare: A social development perspective." Canadian Social Work Review 17 (2000): 13-28

[5] Kusnadi, M. A. Konflik Sosial Nelayan, Kemiskinan dan Perebutan Sumber Daya Perikanan. LKIS PELANGI AKSARA, 2002.

[6] Sugiyono, Prof Dr. "Metode penelitian pendidikan." Pendekatan Kuantitatif (2010).

[7] Nunnally, Jum C. "Psychometric theory-25 years ago and now." Educational Researcher 4.10 (1975): 7-21.

[8] Ghozali, Imam. "Aplikasi Analisis Multivariate dengan Program IBM SPSS. Yogyakarta: Universitas Diponegoro." (2012).

[9] Hasbullah, Jousairi. Social capital: Menuju keunggulan budaya manusia Indonesia. MR-United Press, 2006.

[10] Pretty, Jules, and Hugh Ward. "Social capital and the environment." World development 29.2 (2001): 209-227.

[11] Hobbs, G. "What is Social Capital? A Brief Literature Overview, Economic and Social Research Foundation, Caledonia." (2000)

[12] Yustika, Ahmad Erani. "Ekonomi kelembagaan: paradigma, teori, dan kebijakan." Penerbit Erlangga. Jakarta (2012).

[13] Todaro, Michael P., and Stephen C. Smith. "Economic development." George Washington University (2012).

[14] Sholihin, Mahfud, and Dwi Ratmono. Analisis SEM-PLS dengan WarpPLS 7.0 untuk Hubungan Nonlinier dalam Penelitian Sosial dan Bisnis. Penerbit Andi, 2021.

[15] Kenny, David A. "Mediation with dichotomous outcomes." Research Note, University of Connecticut (2008). 
[16] Widayanti, Sri. "Pemberdayaan masyarakat: pendekatan teoritis." Welfare Jurnal Ilmu Kesejahteraan Sosial 1.1 (2012).

[17] Mubarak, Zaki. Evaluasi Pemberdayaan Masyarakat Ditinjau Dari Proses Pengembangan Kapasitas Pada Kegiatan Pnpm Mandiri Perkotaan Desa Sastrodirjan Kabupaten Pekalongan. Diss. Universitas Diponegoro, 2010.

[18] Mukhrizal, Arif. Pendidikan posmodernisme: telaah kritis pemikiran tokoh pendidikan. Ar-Ruza Media, 2014.

[19] Braunack-Mayer, Annette, and Jennie Louise. "The ethics of community empowerment: tensions in health promotion theory and practice." Promotion \& Education 15.3 (2008): 5-8.

[20] Lestari, Retno Budi, and Rini Aprilia. "Membangun Nation Branding dalam Upaya Meningkatkan Daya Saing Sektor Pariwisata Indonesia." Prosiding PESAT 5 (2013). 